\title{
Basal Cell Nevus Syndrome : A Case Report
}

\author{
Jeeyoun Kim, Sohee Oh \\ Department of Pediatric Dentistry, Sacred Heart Hospital, Hallym University
}

\section{Abstract}

The basal cell nevus syndrome is also known as the Gorlin-Goltz syndrom. It is a dominant autosomal disorder which is characterized by keratocystic odontogenic tumors in the jaw, skeletal abnormalities, and multiple basal cell nevi carcinomas. This study reports an 11-year-old boy with multiple odontogenic keratocysts in the jaw, hypertelorism, and frontal bossing. When a young patient has cystic lesions with an impacted permanent teeth, it is important to preserve the teeth. For a growing patient with impacted permanent teeth, a more conservative method is suggested, which will enable the preservation the permanent teeth in Gorlin-Goltz syndrome.

Key words : Basal cell nevus syndrome, Impacted permanent teeth, Keratocystic odontogenic tumor

\section{I. 서 론}

기저세포 모반 증후군, Gorlin-Goltz syndrome은 발병률 $1: 60,000$ 이며 ${ }^{1}$, 남녀 성비의 차이가 없이 일반적으로 임상증 상이 30세 이전에 발생한다2). 1894년 처음으로 보고된 이래 로, 1959년 Howell과 $\mathrm{Caro}^{3}$ 가 피부암 등이 기저세포 모반과 관련 있음을 밝히고, 1960 년 Grolin과 Goltz"는 다수의 기저 세포 암종, 이열 늑골 그리고 악골의 다발성 낭과 같은 임상 소 견이 함께 나타난 환자 2 명을 발표하며 증후군으로 제시하였 다. 1982년 Howell과 Anderson ${ }^{5}$ 은 이 증후군의 특징으로 5 가지 주요 소견인 다발성 기저세포 모반, 악골 낭, 이열 늑골, 손, 발바닥의 소와, 이소성 석회화를 발표하였다. 특히 한국인 에서는 다발성 각화낭성 치성종양, 손, 발바닥의 소와, 그리고 양안 격리증이 높은 임상적 특징으로 나타난다고 한다 ${ }^{6}$.

치과 영역에서 기저세포모반 증후군 환자의 치료는 악골에 발생한 다발성 낭종에 대한 치료와 낭종에 이환된 매복된 치아 에 대한 치료가 주된 관심사이다. 낭종으로 인하여 발생한 악골 의 결손부는 다양한 형태의 이식재를 통하여 치료될 수 있으며
이때 사용할 수 있는 이식재 중에서 가장 우선적으로 고려되는 것은 자가골 이식이나 증후군 환자의 경우 나이가 어린 경우가 많아서 적합한 자가골 이식의 공여부를 찾기가 어려운 경우가 많다. 이러한 경우에는 동종골이나 이종골을 이용한 이식도 고 려할 수 있다.

본 증례에서는 낭종 적출술 및 이종골 이식술과 교정 치료를 통하여 양호한 결과를 얻어 이에 보고하는 바이다.

\section{II. 증례 보고}

만 11세 남아로 2010년 2월 하악 좌측 제 1,2 유구치 하방 종창을 주소로 본원에 내원하였다. 환아는 출생 직후 삼각두 (trigonocephaly, metopic suture synostosis)로 서울대학교 병원에서 두개성형술을 받았으며 경도의 뇌실확장(ventriculomegaly)이 있었으나 수두증에 대한 치료를 요할 정도가 아니 어서 경과를 관찰 중이었다. 환자의 방사선 검사 결과 상악 좌, 우측 견치 부위, 상악 좌측 제 2,3 대구치부위, 하악 우측 제 1 , 2,3 대구치 부위, 하악 좌측 제 1,2 , 3 대구치부위, 하악 전치부

Corresponding author: Sohee Oh

Department of Pediatric Dentistry, Sacred Heart Hospital, Hallym University, 22, Gwanpyeong-ro 170 beon-gil, Dongan-gu, Anyang-si, Gyeonggi-do, 431-796, Republic of Korea

Tel: +82-31-380-3870 / Fax: +82-31-380-1726 / E-mail: pedopia@hallym.ac.kr

Received November 5, 2013 / Revised November 27, 2013 / Accepted November 27, 2013 
하방 부위에 매복된 하악 좌측 견치를 포함하는 다양한 크기의 각화낭성 치성종양을 보였으며 임상적으로는 하악 좌측 제 1,2 유구치 부위의 협측피질골의 비박, 팽윤이 관찰되었으며 양안 격리증 및 전두정 융기를 보였다(Fig. 1).

만 11세에 전신마취 하에 상악 좌, 우측 견치부위, 상악 좌측 제 $1,2,3$ 대구치부위, 하악 우측 제 1,2 , 3대구치부위, 하악 좌 측 제 2,3 대구치부위, 하악 전치부 하방 부위의 각화 낭성 치성 종양의 낭종 적출술 및 상악 좌측 제 3 대구치, 하악 좌, 우 제3 대구치의 발치를 시행하였고, 낭종 적출술 후 인공골 $\left(\mathrm{Bio}^{-} \mathrm{Oss}^{\circledR}\right.$ Collagen (BOC), Geistlich Pharma AG, Wolhusen, Switzerland)을 이식하여 골 형성을 도모하였다. 낭종으로 인
하여 하악 하연 부위에 매복되었던 하악 좌측 견치의 보존적 치 료를 위하여 이식재 상에 재위치 하였다(Fig. 2). 술 후 조직 검 사 결과 하악 우측 제 2,3 대구치부위, 하악 좌측 제 2,3 대구치 부위, 하악 전치부 하방 부위에서 Hematoxyllin and eosin 염 색에서 낭종의 내면은 주름진 형태로 5 10층 이하의 중층편평 상피세포로 덮여 있었고 하층 결합조직은 얇고 불규칙한 콜라 겐 다발로 이루어져 있어 전형적인 각화낭성 치성종양의 조직 학적 소견을 보여주었다(Fig. 3).

가장 큰 각화낭성 치성종양을 보였던 하악 전치부 및 좌측 견 치 이외의 수술 부위는 큰 이상 없이 치료되었으나 하악 전치부 및 하악 좌측 견치 부위는 인공 골 이식으로 인한 골 석회화 소
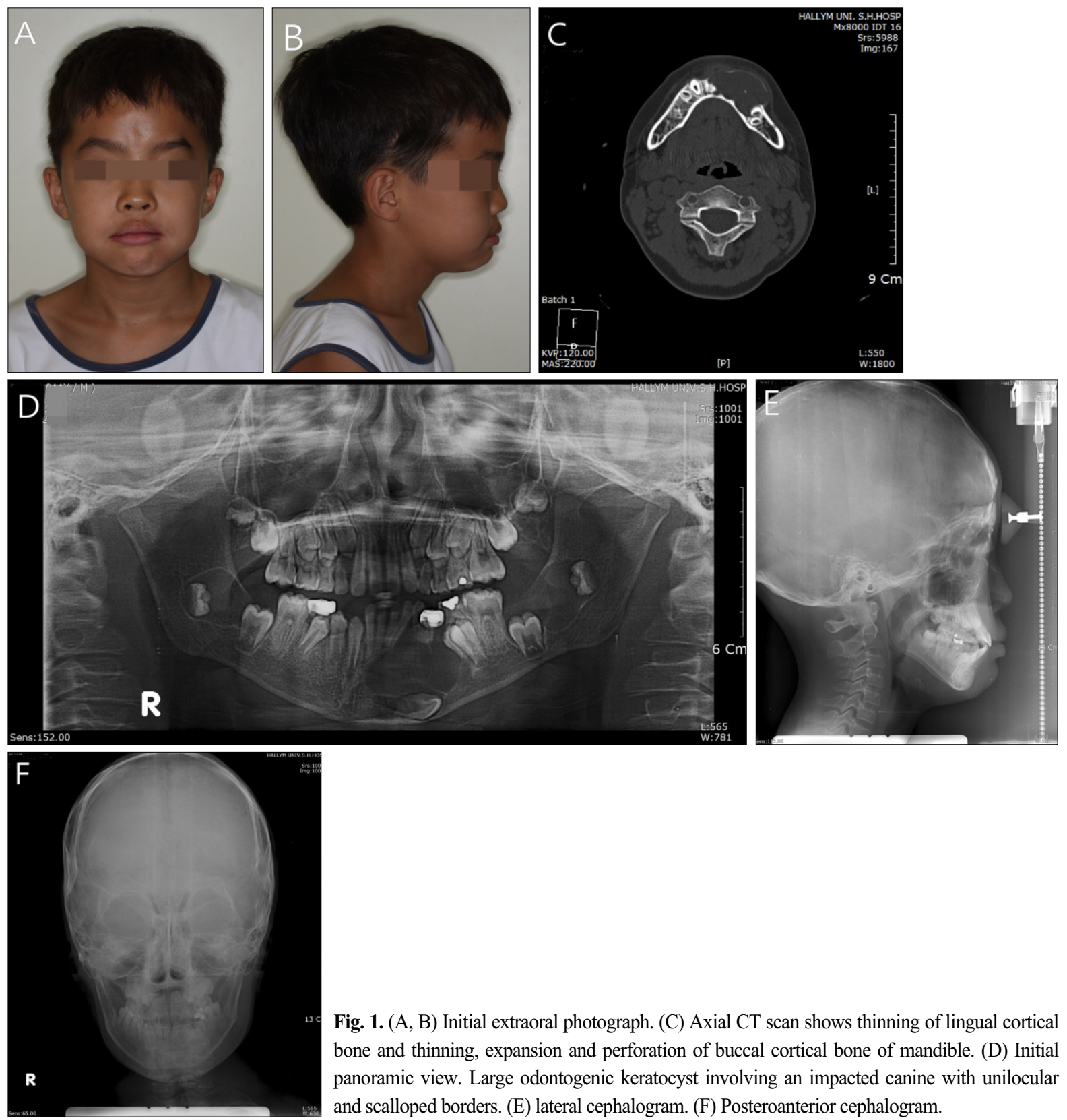

Fig. 1. (A, B) Initial extraoral photograph. (C) Axial CT scan shows thinning of lingual cortical bone and thinning, expansion and perforation of buccal cortical bone of mandible. (D) Initial panoramic view. Large odontogenic keratocyst involving an impacted canine with unilocular and scalloped borders. (E) lateral cephalogram. (F) Posteroanterior cephalogram. 

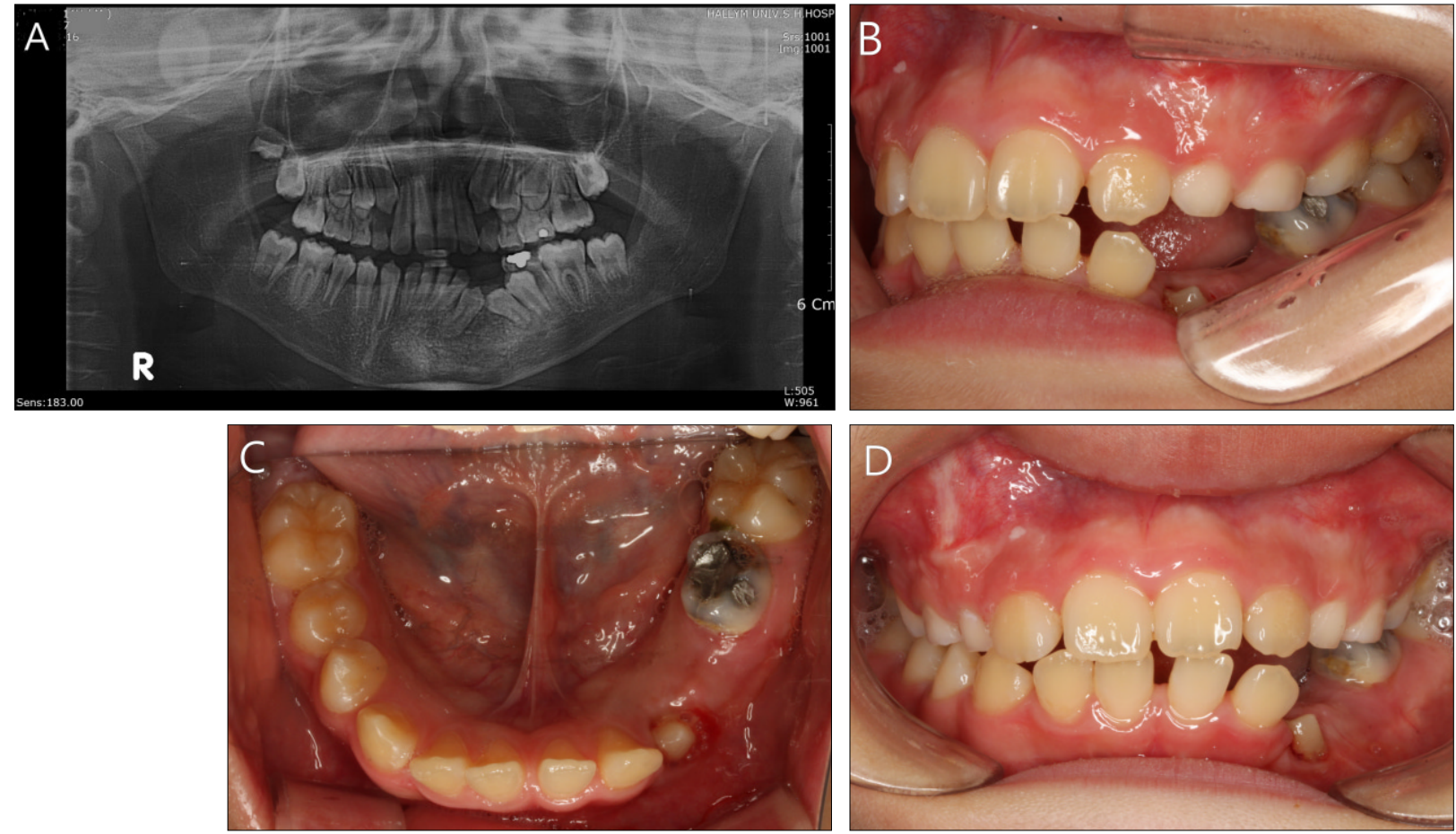

Fig. 2. (A) Panoramic view of after cyst enucleation and xenograft. (B)(C)(D) Intraoral photograph after surgery.

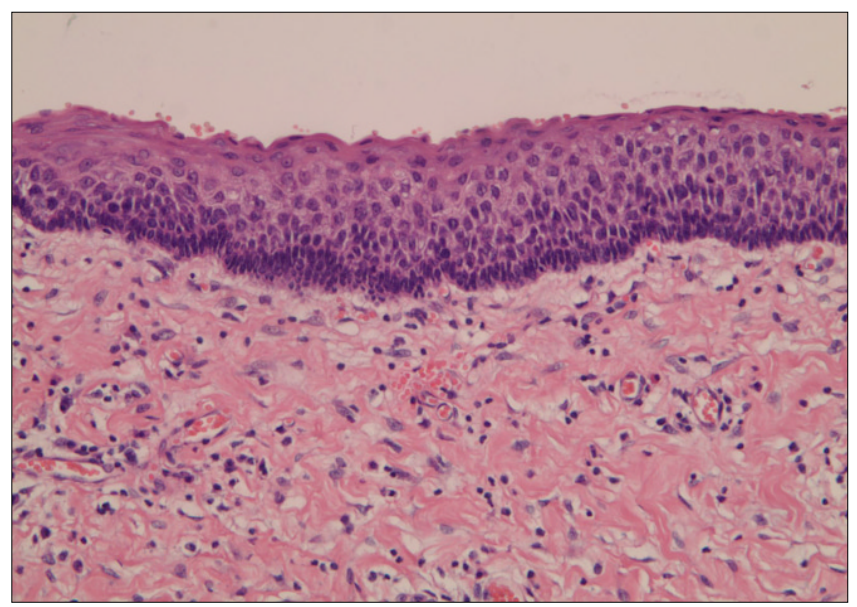

Fig. 3. Pathological finding exhibits the histological features of a keratocystic odontogenic tumor of lower left canine area(Haematoxylin and eosin stain, original magnification: X 400).

견이 나타났다(Fig. 4). 낭종 적출술 후 낭종으로 인하여 변위 및 매복되었던 치아의 자발적 맹출을 기대하였으나, 자발적 맹 출이 이루어지지 않아 수술 1 년 후 미맹출 된 하악 좌측 제 1 소 구치, 그리고 하악 좌측 견치의 치관에 교정 버튼을 부착하여 교정적으로 정출시키기 시작하였다(Fig. 5). 이후 하악 치열에 에지와이즈 장치를 사용하여 교정치료를 시행하였다. 수술 후 3 년 8개월이 지난 지금, 각화낭성 치성종양이 있었던 위치인

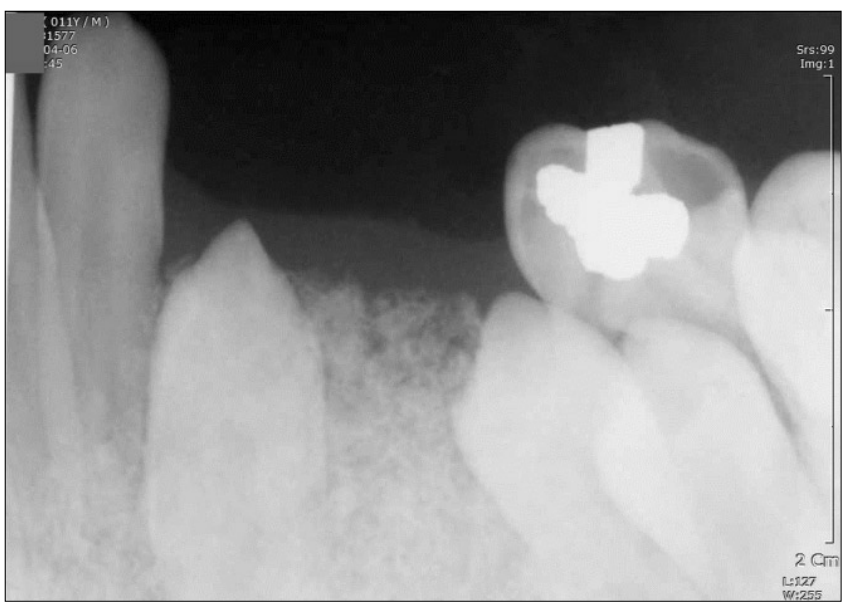

Fig. 4. 2 month after xenograft and lower left canine replantation.

하악 정중부의 경우, 방사선 사진 상으로 낭종 부위는 재발 소 견 없이 잘 치유되고 있으며 변위되었던 하악 좌측 제 1 소구치 의 적절한 배열을 이루었으며 이식된 이종골의 일부는 여전히 방사선 불투과성 결절로 관찰되었다. 각화낭성 치성종양으로 인하여 하악 하연에 매복되어 있었던 하악 좌측 견치의 경우, 골성 유착을 보여 외과적으로 재식 후 경과 관찰 중이다(Fig. $6,7)$. 

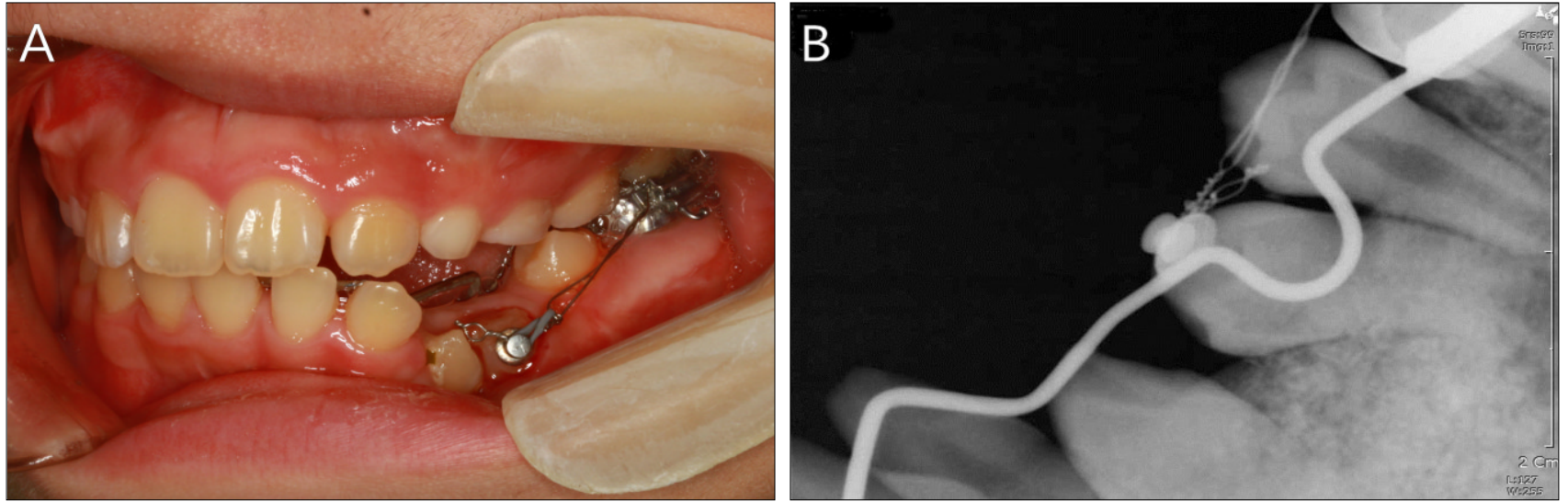

Fig. 5. (A) Intraoral photograph of 1 year after cyst enucleation, orthodontic traction of lower left canine and first premolar. (B) Periapical view of 1 year after cyst enucleation, orthodontic traction of lower left canine and first premolar.
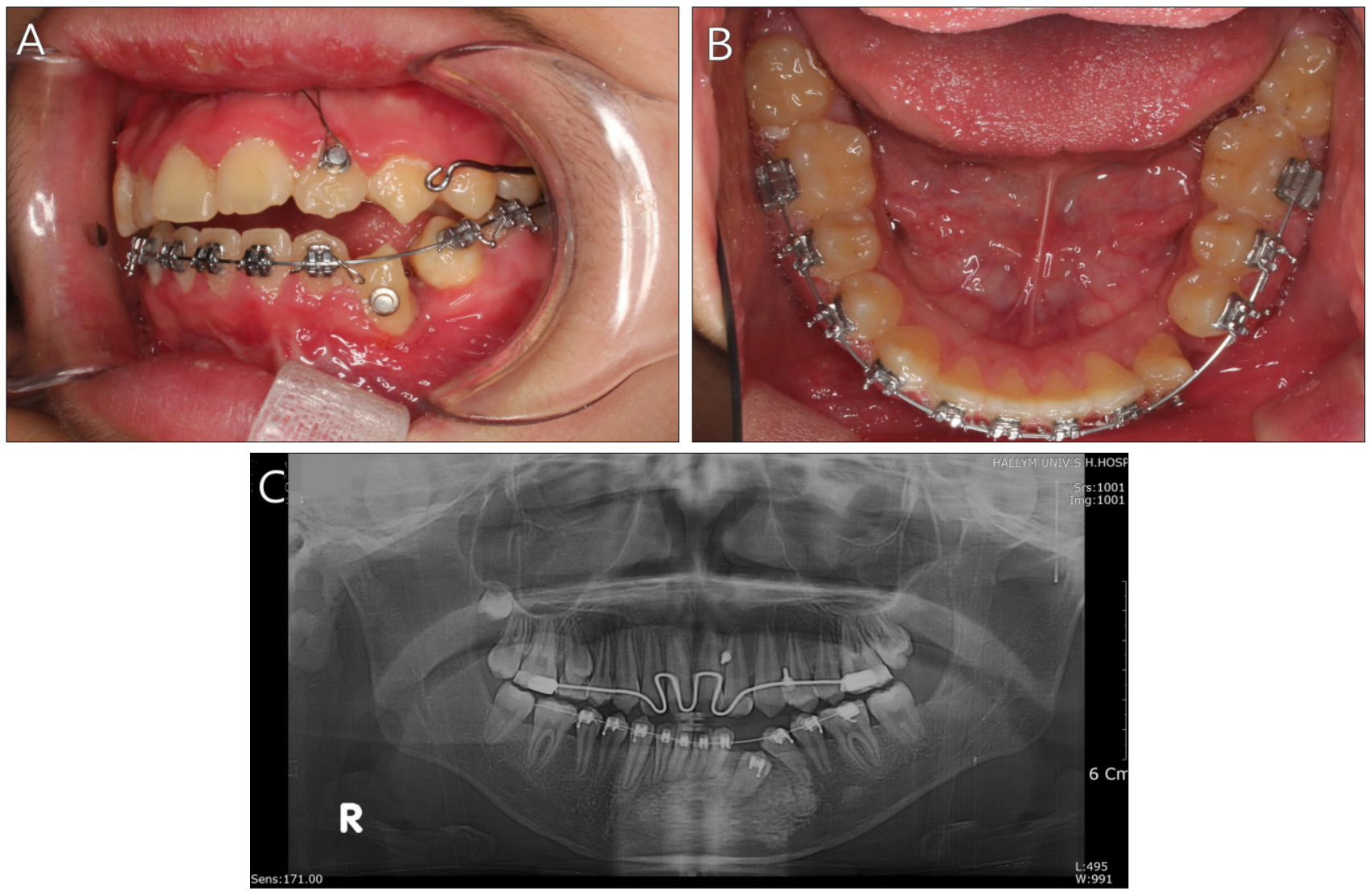

Fig. 6. (A, B) Intraoral photograph of 3 years after surgery. Extracted lower left canine was put into position by preparing the reimplantation site at the apical end of the socket to accommodate the tooth in the new position. (C) Panoramic view of 3 years after surgery. Radiographically, no cystic lesion was detected and new bone formation is observed. 

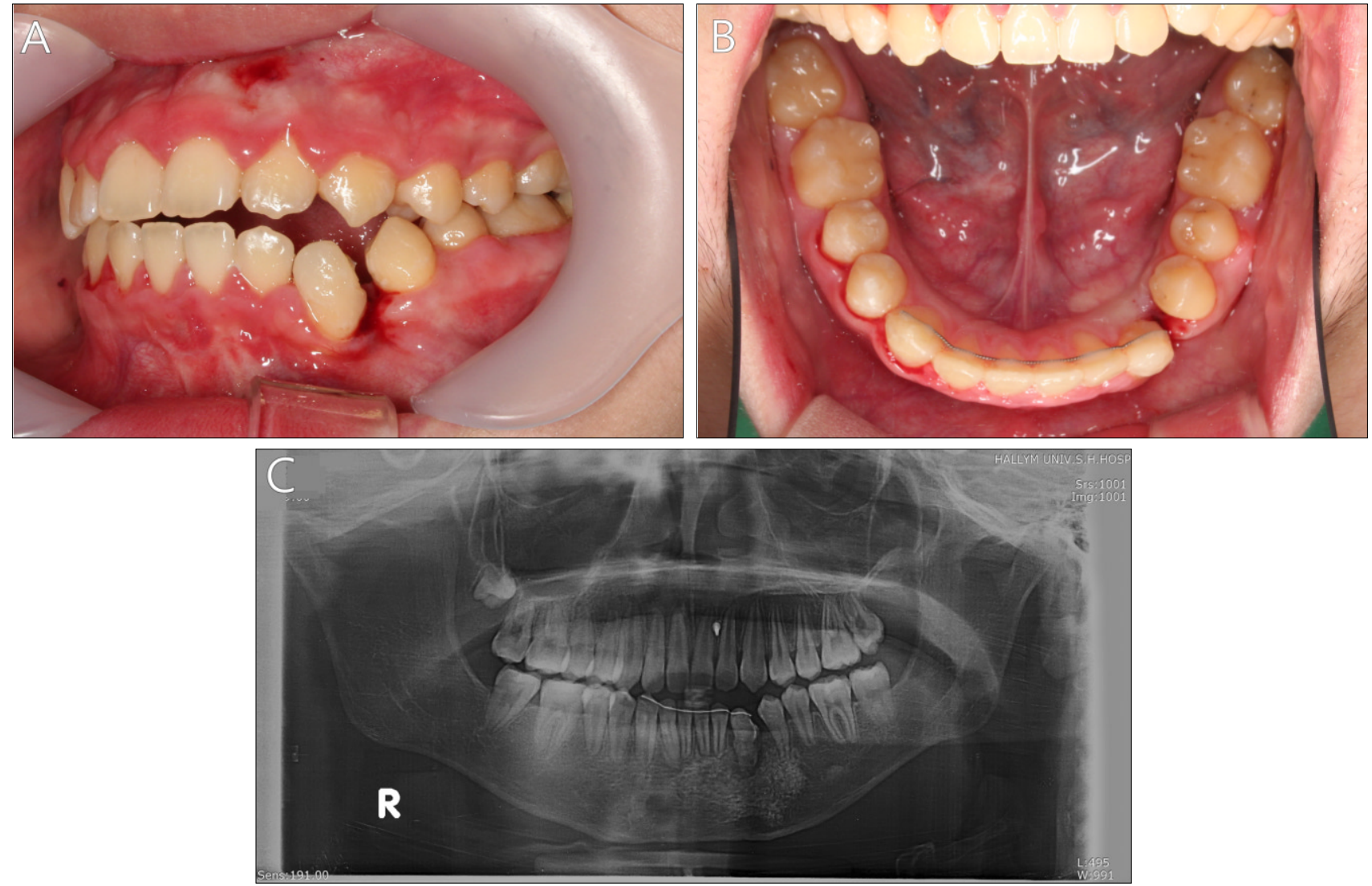

Fig. 7. (A, B) Intraoral photograph of 3 years 8 month after surgery. (C) Panoramic view of 3 years 8 month after surgery.

\section{III. 총괄 및 고찰}

기저세포모반증후군 환자의 $65 \sim 100 \%$ 에서 악골의 각화낭 성 치성종양이 발생한다 ${ }^{7.8)}$. 각화낭성 치성종양은 위성 낭, 가성 및 진성 각화 상피로 재발의 가능성이 높다9). 일반적인 각화낭 성 치성종양의 발생 연령은 우리나라에서 평균 30.8세이지만 이 증후군에서 발생한 각화낭성 치성종양의 경우, 발생 연령이 평균 22 세로 나타나 조기에 발생함을 알 수 있다 ${ }^{10)}$. 본 환자의 경우 11 세에 발견되어 평균보다 이른 시기에 발생하여 내원한 것을 알 수 있다.

기저세포모반증후군은 종양억제 유전자로 알려진 염색체 9q22.3이 원인 유전자로 상염색체 우성으로 97\% gene penetrance를 갖지만 환자의 증상은 다양하게 나타난다 ${ }^{11.12)}$. 또한 Patched (PTCH)라 불리는 $9 \mathrm{q} 22.3$ 염색체 상에 위치하는 종 양억제유전자가 기저세포 모반 증후군의 원인으로 밝혀졌고 1,13) 그 이외에도 Patched 2 (PTCH2), Smmothened (SMO), Sonic hedgehog (SHH)유전자가 원인으로 밝혀져 있다 ${ }^{14)}$. 본 환자의 부모와 다른 형제 검사 결과 정상으로 판명되 었으며 문진 결과 가족력은 없었다.
1976 년 $\mathrm{Brannon}^{15)}$ 은 각화낭성 치성종양의 높은 재발률에 대하여 위성 세포의 존재, 낭종의 불완전한 적출, 주변 부위의 각화낭성 치성종양 재발을 이유로 들었다. 각화낭성 치성종양 의 치료 방법에는 낭종 적출술, carnoy's solution과 함께 낭종 적출술을 시행하는 방법, 조대술, 그리고 골 절제술이 있다. 각 화낭성 치성종양의 치료를 위해 Nakamura ${ }^{16)}$ 는 각화낭성 치성 종양으로 매복된 치아가 조대술 혹은 감압술 후 정상 맹출하는 경우를 보고하였다. 또한 Pogrel ${ }^{17)}$ 은 조대술을 시행한 13 개의 증례 보고를 통해 각화낭성 치성종양이 임상적, 방사선학적으 로 없어졌음을 보고하였으며 조대술 시행시, interleukin-1a와 세포 증식 등이 억제되면서 각화낭성 치성종양의 침습적인 성 향이 감소됨이 보고된 바 있다 ${ }^{18)}$. 그러나 조대술 시행시 두 번의 수술이 필요할 수 있으며 낭종 조직을 남겨 놓는다는 문제점과 재발 가능성이 낭종 적출술에 비하여 높다는 점이 있다 ${ }^{19,20)}$. 낭종 적출술과 carnoy's solution을 사용한 경우, 골 절제술과 비슷 한 수준으로 재발률을 낮출 수 있지만 본 증례와 같이 하치조 신경이 낭종 부위에 이환된 경우, 지각 마비와 같은 부작용이 있을 수 있다 ${ }^{211}$. 골 절제술의 경우에는 안면 변형, 치아의 상실, 이식골의 감염, 하치조 신경이 낭종 부위 이환시의 감각소실과 
같은 부작용을 나타낼 수 있다 ${ }^{19)}$. 그리하여 가장 낮은 재발률을 나타내는데도 불구하고, 잔여 성장량이 남은 청소년기 이전의 환자에서는 이와 같은 부작용으로 인하여 일반적으로 사용되지 않는다. 본 환자에서는 각화낭성 치성종양과 병소에 의해 하악 하연으로 변위된 치아의 치료를 위해 각화낭성 치성종양의 적 출술 후 병소에 이환된 치아의 의도적 재위치 및 낭종 적출 후 발생한 골 결손부에 대한 이종골 이식을 시행하였다. 낭종은 수 술 후 3 년이 지난 현재 재발 소견 없이 골 결손부는 잘 치유되 었으며 흡수되지 않고 남아있는 것으로 보이는 이식골이 방사 선 불투과성 결절로 관찰되었다. 또한 하악 부위의 지각 이상 없이 정상적인 소견을 보이고 있다.

이종골 이식 부위의 잔여 성장에 대하여는 보고된 바가 거의 없다. 상기 증례의 경우 이식 부위에 잔존 이식재로 보이는 방 사선 불투과성 결절이 다수 관찰되는 데, 이종 이식재의 경우 오랜 기간 흡수되지 않고 잔존한다는 보고가 다수 존재한다리 하지만 이러한 잔존 이식재가 환자의 성장에 미치는 영향에 대 하여는 체계적으로 연구된 논문이 거의 없다. 성장기 아동에서 이종골 이식재가 악안면 영역에 사용된 경우에 치조열 환자에 서 견치의 맹출을 유도하기 위하여 사용된 증례가 보고된 바 있 다 ${ }^{23)}$. 이들 증례에서 이식재로 인한 성장 장애는 보고된 바 없고 치아의 이동도 성공적으로 일어난 것으로 대부분 보고하고 있 다 ${ }^{24)}$. 본 증례에서도 이식재 상의 치아들이 교정력에 의하여 이 동된 것으로 보여 이식재의 사용이 성장기 아동에서 치아 이동 에 미치는 영향은 없는 것으로 보인다. 향후 하악 골 성장 양상 은 추가적인 관찰이 필요하나 이식재의 사용으로 인한 골 성장 장애는 없을 것으로 보인다.

\section{IV. 요 약}

기저세포 모반 증후군을 가진 환자의 치료에서 각화 낭성 치 성종양의 낭종 적출술과 이종골 이식술 후 낭종에 의해 변위된 치아의 보존적 치료를 위해 교정력을 이용하여 치아의 이동을 시도하여 적절한 배열을 이루었고, 하악 하연 부위에 매복되었 던 하악 좌측 견치의 경우, 골성 유착을 보여 외과적 재식술 후 경과 관찰 중으로 특이 사항은 발견되지 않고 있다. 수술 부위 역시 술 후 약 3 년 8 개월이 지난 지금, 재발 소견은 관찰되지 않고 있다. 추후 낭종의 재발 및 기저세포 모반 증후군의 여러 이상 증상을 고려하여 주기적인 검사가 필요하다.

\section{References}

1. Gorlin RJ : Nevoid basal cell carcinoma (Gorlin) syndrome: unanswered issues. J Lab Clin Med, 134: 551-552, 1999

2. Nicolatou O, Kakarantza-Angelopoulou E : Odontogenic keratocysts: clinicopathologic study of 87 cases. J Oral Maxillofac Surg, 48:593-599, discussion 599-600, 1990.
3. Howell JB , Caro MR : The basal-cell nevus: its relationship to multiple cutaneous cancers and associated anomalies of development. AMA Arch Derm, 79:67-77, discussion 77-80, 1959.

4. Gorlin RJ : Nevoid basal cell carcinoma syndrome. Dermatol Clin, 13:113-25, 1995.

5. Howell JB, Anderson DE : "The basal-cell nevus" by Howell and Caro, January 1959. Commentary: The nevoid basal cell carcinoma syndrome. Arch Dermatol, 118:813-826, 1982.

6. Ahn SG, Lim YS, Kim DK, et al. : Nevoid basal cell carcinoma syndrome: a retrospective analysis of 33 affected Korean individuals. Int $J$ Oral Maxillofac Surg, 33:458-462. 2004.

7. Evans DG, Ladusans EJ, Rimmer S, et al. : Complications of the nevoid basal cell carcinoma syndrome: results of a population based study. $J$ Med Genet, 30:460-464, 1993.

8. Southwick GJ, Schwartz RA : The basal cell nevus syndrome: disasters occurring among a series of 36 patients. Cancer, 44:2294-2305, 1979.

9. Stoelinga PJ, Peters JH, van de Staak WJ, et al. : Some new findings in the basal-cell nevus syndrome. Oral Surg Oral Med Oral Pathol, 36:686-692, 1973.

10. Myoung H, Hong SP, Hong SD, et al. : Odontogenic keratocyst: Review of 256 cases for recurrence and clinicopathologic parameters. Oral Surg Oral Med Oral Pathol Oral Radiol Endod, 91:328-333, 2001.

11. Gorlin RJ, Sedano HO : The multiple nevoid basal cell carcinoma syndrome revisited. Birth Defects Orig Artic Ser, 7:140-148, 1971.

12. Howell JB : Nevoid basal cell carcinoma syndrome. Profile of genetic and environmental factors in oncogenesis. J Am Acad Dermatol, 11:98-104, 1984.

13. R Yang X, Pfeiffer RM, Goldstein AM : Influence of glutathione-S-transferase (GSTM1, GSTP1, GSTT1) and cytochrome p450 (CYP1A1, CYP2D6) polymorphisms on numbers of basal cell carcinomas (BCCs) in families with the naevoid basal cell carcinoma syndrome. J Med Genet, 43:16, 2006.

14. Cohen MM Jr : Nevoid basal cell carcinoma syndrome: molecular biology and new hypotheses. Int $J$ Oral Maxillofac Surg, 28:216-23, 1999.

15. Brannon RB : The odontogenic keratocyst. A clinicopathologic study of 312 cases. Part I. Clinical features. Oral Surg Oral Med Oral Pathol, 42:54-72, 1976.

16. Nakamura, N, Mitsuyasu T, Mitsuyasu Y, et al. : 
Marsupialization for odontogenic keratocysts: longterm follow-up analysis of the effects and changes in growth characteristics. Oral Surg Oral Med Oral Pathol Oral Radiol Endod, 94:543-553, 2002.

17. Pogrel MA : Decompression and marsupialization as a treatment for the odontogenic keratocyst. Oral Maxillofac Surg Clin North Am, 15:415-427, 2003.

18. Ninomiya, T, Kubota Y, Koji T, et al. : Marsupialization inhibits interleukin-1alpha expression and epithelial cell proliferation in odontogenic keratocysts. $J$ Oral Pathol Med, 31:526-533, 2002.

19. Nakamura N, Mitsuyasu T, Mitsuyasu Y, et al. : Marsupialization for odontogenic keratocysts: longterm follow-up analysis of the effects and changes in growth characteristics. Oral Surg Oral Med Oral Pathol Oral Radiol Endod, 94:543-53, 2002.

20. Thomas M, Tackett JC, Desai P : The incredible odontogenic keratocyst. N Y State Dent J, 58:31-3, 1992.

21. Loescher AR, Robinson PP : The effect of surgical medicaments on peripheral nerve function. Br J Oral Maxillofac Surg, 36:327-32, 1998.

22. Valentini P, Abensur D, Densari D, et al. : Histological evaluation of Bio-Oss in a 2-stage sinus floor elevation and implantation procedure. A human case report. Clin Oral Implants Res, 9:59-64, 1998.

23. Goudy S, Lott D, Burton R, et al. : Secondary alveolar bone grafting: outcomes, revisions, and new applications. Cleft Palate Craniofac J, 46:610-612, 2009.

24. Boyne PJ : Application of bone morphogenetic proteins in the treatment of clinical oral and maxillofacial osseous defects. J Bone Joint Surg Am, 83:146150, 2001. 
국문초록

\section{기저세포 모반 증후군 : 증례보고}

\section{김지연 · 오소희}

한림대학교 성심병원 소아치과

기저세포 모반 증후군은 상염색체 우성 방식으로 유전되는 질환으로 다발성 각화낭성 치성종양, 대두증 및 두정골 융기, 골격계 기형 등을 보이는 질환이다. 다발성 각화낭성 치성 종양, 두정골 융기, 양안격리증을 가진 만 11 세 환자의 하악과 상 악에서 발생한 다양한 크기의 낭종에 대한 적출술과 이종골 이식술을 시행 후 교정적 견인을 시행하였다. 낭종에 의한 매복 영구치를 가진 성장중인 기저세포 모반 증후군 환자에서의 보존적인 치료를 하였기에 문헌고찰과 더불어 보고하고자 한다.

주요어: 기저세포 모반 증후군, 매복 영구치, 각화낭성 치성종양 